\title{
Auditory Processing in People with Chronic Aphasia
}

\author{
Katarina Pavičić Dokozaª , Zdravko Kolundžićé, Mladen Heđever \\ ${ }^{1}$ The SUVAG Polyclinic, Zagreb, Croatia \\ ${ }^{2}$ County Hospital Požega, Požega, Croatia \\ ${ }^{3}$ Faculty of Education and Rehabilitation Sciences, Zagreb, Croatia
}

\begin{abstract}
A B S T R A C T
The preconditions for successful voice communication are good hearing and listening, and auditory processing that includes the ability to process the audio signal. Damage or deceleration of sound signal processing at any level from the periphery to the central structures leads to disintegration and inability to process the signal effectively. Auditory processing in people with aphasia has not been examined in Croatia to date. Results of studies conducted in other languages point to negative effects of auditory processing difficulties on the receptive and expressive component of the language. This study was conducted on a sample of subjects with chronic aphasia and a group of control subjects with no neurological or any other disorders that can affect auditory processing. The inclusion criteria for persons with aphasia were impaired language skills as a result of cerebrovascular accident that occurred at least six months before the examination, regardless of severity and type of aphasia and normal hearing status. The study did not include persons with aphasia who were unable to repeat the six-word sentence, due to impaired comprehension or speech expression, and those whose comprehension was not sufficient to cooperate well during the test. The test was conducted individually for 30 minutes per subject using the Auditory processing test (PSP) that is standardized for the Croatian language. Results from this study showed statistically significant lower achievement on all subtests on PSP-1 (filtered words, speech in noise, dichotic words test, and dichotic sentence test) in people with aphasia compared with the control group. People with aphasia and control group subjects showed better results in favor of the left ear on variable speech in noise. Filtered words were easily processed through the left ear in people with aphasia while dichotic sentences were easily processed through the left ear in the control group. The results of this study confirm the hypothesis of the presence of auditory processing difficulties in people with aphasia and are consistent with previous studies conducted in other languages. In addition, the study points to the need of introducing specific therapeutic procedures in rehabilitation in order to improve the function of auditory processing in persons after a cerebrovascular accident.
\end{abstract}

Key words: aphasia, CVI, auditory processing, language, communication

\section{Introduction}

The consequences of a stroke on a person's life can be significant and, in many cases, impede or completely impair the ability for verbal or nonverbal communication. Difficulties are manifested in the fields of language comprehension and expression, non-verbal communication, and motor, cognitive and auditory functioning. Aphasia is a disorder of language ability resulting from damage to the central nervous system (disease, trauma, cerebrovascular accident) that results in the disintegration of receptive and/or expressive spoken/written language.

Auditory processing disorder (APD) is a sensory disorder that most commonly affects listening, speech compre- hension and learning, and creates difficulties in processing auditory information. APD is not caused by impairment of peripheral hearing or cognitive function, but it is a disorder caused by difficulty in understanding the stimulus that is the acoustic signal. The auditory processing disorder is a deficit in the processing of information presented aurally, and inappropriate acoustic conditions can significantly affect this disorder ${ }^{1}$.

Auditory processing disorder, in terms of the efficacy in which the central nervous system processes and uses auditory information, can occur as well as an associated disorder with some other conditions, such as language

Received for publication March 27, 2020 
disorders, specific reading disorders, ADHD, neurodegenerative diseases and aphasia.

Effective auditory processing begins with the detection of a sound signal at the cochlea level, while pre-lingual and linguistic processing occurs at the level of subcortical and cortical structures. Damage or deceleration of the sound signal processing at any level from the periphery to the central structures leads to disintegration and inability to process the signal effectively. Considering the structural changes that occur at the level of the central nervous system as a result of stroke, impaired auditory processing probably will be outcome the in most individuals with aphasia. Also, the use of auditory stimuli in unconscious patients is an area that is developing significantly, with the potential to define distributed brain mechanisms relevant to functional recovery from coma or vegetative states $^{2}$.

Studies that examine the impact of stroke on auditory processing ability in individuals with aphasia are rare. A meta-analysis conducted in the study by Nascimento et al. ${ }^{3}$ has highlighted the benefit of the left ear advantage (Left Ear Advantage - LEA) in a person with aphasia ${ }^{4-7}$. The above-mentioned hypothesis of the benefits of the left ear is based on the model of dichotic perception ${ }^{8}$, which favors the contralateral route of transmission of auditory information over the ipsilateral route.

Ortiz and Peroni ${ }^{9}$ have studied the impact of aphasia on visual functions and attention. Their respondents repeated the sentences in terms of dichotic listening at the level of competitive contralateral and ipsilateral conditions. In both conditions, significantly better results were achieved by control group.

Shisler ${ }^{10}$ investigated the impact of disintegration on auditory extinction ${ }^{9}$. The results confirmed significantly worse achievement in individuals with aphasia on tasks that required integration skills.

Therefore, the concept of auditory processing is a complex phenomenon that refers to a person's ability to perceive, differentiate and process different auditory information, and is most often associated with the inability to listen well ${ }^{11}$, which occurs in the absence of hearing impairment at the peripheral level.

In order to separate the auditory processing disorder (listening phenomenon) from the possible effects of language impairment on listening ability, the British Association of Audiologists ${ }^{12}$ recommended that non-speech tasks should be used as a stimulus. Although ASHA ${ }^{13}$ also identified impaired auditory processing as a difficulty or impaired listening ability, including the ability to discriminate, sequence, and localize sound, but did not recommend use of non-speech stimulus.

Auditory processing test, Test PSP-1 is, for the time being, the first and only test in Croatian-speaking regions that enables the difficulties regarding auditory processing disorders. As there has been no research that explores the impact of stroke on auditory processing ability in native speakers, the aim of this study was to apply the PSP-1 test in subjects with aphasia. Considering the results of for- eign research, the research was based on two questions: is auditory processing worse in people with aphasia and do they have a pronounced preference for the left ear.

\section{Materials and Methods}

Persons with chronic aphasia resulting from a stroke that occurred at least six months before the study were included in study. All subjects were subjected to triage audiometry (part of the PSP-1 test) prior to conducting the auditory processing test. Only participants with no deviations at the peripheral hearing level were included in study. The basic criterion for inclusion in the research was the ability to repeat a sentence with at least six elements. Diagnosis of aphasia was established by a speech and language pathologist after referral for speech therapy due to a cerebrovascular accident (CVA). All participants were recruited from the health institution where they were enrolled in speech therapy.

The control group consisted of middle-aged persons with no known neurological pathology and regular peripheral hearing. A triage audiometry (part of the PSP-1 test) was applied in order to eliminate hearing loss.

All subjects (persons with aphasia and control subjects) were Croatian native speakers. The test sample consisted of two groups of subjects. The first group (group I) consisted of 23 subjects with aphasia (average chronological age was 59 years). The control group (group II) consisted of 17 subjects (average chronological age 42 years). Studies confirm ${ }^{14}$ that a decline in auditory ability occurs after the age of 30 , which is why the control subjects were middle-aged. that is, they were chronologically as close as possible to the experimental group, but also beyond the age showing the best auditory perception test results.

Participation was voluntary; patients and their families were informed that nonparticipation would not affect their treatment. Information about the study was provided before recruitment. Written informed consent was obtained from the patient, and it was a guarantee of data anonymity and confidentiality. The assessment was conducted by a speech and language pathologists who were well skilled with the application of Test PSP-1.

The test was performed using the Auditory Processing Test ${ }^{15}$, with an average duration of 30 minutes per subject. All four sub-tests were applied to all participants in this study: filtered word test, noise speech test, dichotic word test, and dichotic sentence test. Testing of subjects was conducted by the authors of this research. PSP1 is modelled on the revised SCAN - C test that examines auditory processing disorders in children ${ }^{16}$ (Keith, R.W., 2000, according to Heđever 2018) and it is designed entirely in Croatia and for Croatian-speaking regions. The test consists of four subtests.

The filtered word test is a monoaural low-redundant speech test that tests the ability to recognize words that have reduced intelligibility. It allows evaluating the understanding of distorted speech. Testing is performed by 
presenting a series of filtered words (low pass filter with a cutoff frequency at $1 \mathrm{kHz}$ and a damping slope of 32 $\mathrm{dB} /$ oct) to the subject in one ear (monoaural). The test is performed for each ear separately. The test contains two lists of 17 words that are phonologically aligned for the right and left ears so that the selected words contain the same number of voices with respect to the mode and location of the formation and are also equable across the frequency spectrum.

The speech in noise test belongs to the category of monoaural low-redundant speech tests. In this test, the word stimuli are presented without filtering, but in the presence of background noise. Here, the continuous human murmur of a large group of people is used as noise, which must be completely incomprehensible and of constant intensity $8 \mathrm{~dB}$ lower than the level of the word stimuli. The test contains two 14 -word lists that are phonologically, and frequency matched for the right and left ear.

The dichotic word test (word competency test) presents two different words binaurally where one word is heard in one ear and at the same time another word in the other ear. Subjects are asked to repeat the word they heard in one (e.g. right) ear and then the word they heard in the other ear (although both words were presented simultaneously). In the second part of the test, the subject is asked to change the order of the answer (instructions were given to repeat the word from the left ear and then from the right ear). The test contains 15 pairs of words for each ear.

The dichotic sentence test presents two different sentences binaurally and the test is performed in the same way as in the previous word test. This test is also used to assess the degree of maturation and hemispheric dominance for the language, and to detect disorders or damage to the auditory tract of the central nervous system. This test is also called the sentence compression test, or the binaural separation test. The test checks the ability of the subject for direct auditory attention in only one ear while ignoring the auditory stimulus in the other ear. Comparison of the results of the dichotic word test and the dichotic sentence test provides greater certainty in assessing possible language difficulties. The test contains 10 pairs of sentences for each ear (40 sentences in total). Detailed instructions and test protocol are described in the manual ${ }^{16}$.

Each subject was examined individually in a silent room with prior consent to conduct the survey. The administration of PSP-1 test required a silent room so the participant can clearly hear the instruction and stimulus words and sentences incorporated in subtests hereby described. Words and sentences are recorded on an MP4 Player which is connected through an adapter to 2 pairs of headphones. An MP4 Player is already calibrated to equal volume for all subtests. A volume of approximately $60 \mathrm{~dB}$ is pleasant for us and is used as a calibrated volume. Participants are given short instructions from the test administrator what to do after they hear words or sentences in the left, right or both headphones. Same instructions are recorded within every subtest. Before subtests there is a probe stimulus to be sure that the patient understands the instruction. Participants only have to sit still and listen to recorded words and sentences and to do as instructed.

\section{Statistics}

The SPSS computer program was used for statistical data processing. For all quantitative variables, the normality of the frequency distributions was tested by the Shapiro-Wilk test. Descriptive statistics were calculated and data that had a normal distribution of results were processed by parametric methods (t-test and one-factor analysis of variance - ANOVA), while processed data that did not have normal distribution were processed by non-parametric method (Kruskal-Wallis test). Non-parametric rank correlation coefficients (Spearman) were calculated between the variables. Non-parametric methods were used to test differences in left and right ear processing, namely the Mann-Whitney U Test for testing significance of differences between groups of subjects and Sign Test for testing significance of differences between left and right variables on each subtest and for each group of subjects separately

\section{Results}

For independent variables (group, gender), frequencies and proportions were calculated by category of these variables. The results of frequency distribution by category of independent variables are presented in Table 1.

Regarding group 1 (persons with aphasia), it was observed that there were $13(56.5 \%)$ male and $10(43.5 \%)$ female subjects among them. The middle-aged control group was consisted of $6(30.0 \%)$ male and $14(70.0 \%)$ female subjects.

TABLE 1

FREQUENCY AND PROPORTION DISTRIBUTION BY CATEGORY OF INDEPENDENT VARIABLES

\begin{tabular}{ccccc}
\hline Variable name & \multicolumn{3}{c}{ Groups of respondents } \\
\hline Gender & Male - group 1 & Female - group 1 & Male - group 2 & Female - group 2 \\
Frequencies/percentages & $13 / 56.5$ & $10 / 43.5$ & $6 / 30.0$ & $14 / 70.0$ \\
\hline
\end{tabular}


The basic statistics of all dependent variables, for each group separately, are presented in Table 2 . All variables are interval or proportional, so arithmetic means and standard deviations are calculated as the basic statistical indicators. For all quantitative variables, the normality of frequency distributions was tested for each group of subjects by the Shapiro-Wilk test.

\section{TABLE 2}

BASIC STATISTICAL INDICATORS OF ALL DEPENDENT-QUANTITATIVE VARIABLES

\begin{tabular}{lcccc}
\hline Variables & \multicolumn{2}{c}{ Arithmetic means } & \multicolumn{2}{c}{ Standard deviations } \\
Codes & GROUP 1 & GROUP 2 & GROUP 1 & GROUP 2 \\
\hline AGE & 58.50 & 41.58 & 10.37 & 9.33 \\
FWTR & 8.65 & 14.65 & 3.08 & 1.50 \\
FWTL & 11.83 & 14.70 & 3.11 & 0.18 \\
SINR & 6.83 & 11.55 & 3.07 & 1.43 \\
SINL & 8.48 & 11.70 & 2.69 & 1.13 \\
DTWR & 8.48 & 26.80 & 10.21 & 2.02 \\
DTWL & 15.13 & 27.35 & 10.09 & 2.82 \\
DTSR & 3.65 & 9.60 & 4.21 & 0.60 \\
DTSL & 4.57 & 9.95 & 380 & 0.22 \\
SUM & 67.61 & 126.30 & 26.04 & 7.03 \\
TOTAL & & &
\end{tabular}

Legend: FWT - filtered word; SIN - speech in noise; DTW - dichotic word test; DTS - dichotic sentence test; SUM TOTAL - the sum of the scores of all the subtests, R-right, L-left

The smallest and highest scores of all dependent-quantitative variables and the testing of the normality of the frequency distributions by the Shapiro-Wilk test show that the following variables have a normal distribution in both groups of subjects: age, FTWL, SINR and total scores. With these variables, the methods of parametric statistics, the t-test and the analysis of variance can be applied to test for differences between groups. For all other variables, non-parametric data processing methods should be used to test for differences between these groups of subjects.

Methods of parametric and non-parametric statistics were used to test differences between group 1 and group 2. For normally distributed variables such as: age, FWTL,
SINR, and total scores differences were tested using the t-test for two independent samples (Table 3). The other 9 variables do not have a normal frequency distribution in both groups, so a nonparametric Mann-Whitney test was required to test for differences.

Table 3 shows that the variance of the age variable is homogeneous since $\mathrm{p} 1$ is $<44.1 \%$. For all other variables, it was found that the variance was not homogeneous, since p1 $<1.8 \%$. For each variable, according to the significance of the Levene test, the corresponding values for the t-test and the corresponding significance are given.

A statistically significant difference between group 1 and group 2 was obtained with the age variable, since $\mathrm{t}$ (5.590) was significant at the significance level p $2<0.05 \%$. The result was expected due to average age of groups of subjects.

A statistically significant difference was obtained with the mean values of points on the filter word test - left (FWTL), between group 1 and group 2 . The t-test is -3.757 and is significant at the significance level p $<0.1 \%$. Less total points in the filtered word-left test were scored by the subjects with aphasia compared to the control group.

Significant differences between the arithmetic means were also obtained on the Speech in Noise Test - right (SINR). The t-test is -6.601 and is statistically significant at a significance level of p $<0.05 \%$. Considering the negative difference between the arithmetic means (-4.724), it can be concluded that the average results on speech in noise-right test is achieved by the subjects with aphasia compared to the control group.

A large difference in arithmetic means between the subjects with aphasia and the control group was obtained on the total scores variable. The t-test is -10.383 and is statistically significant at a significance level of $\mathrm{p} 2$ $<0.05 \%$. Due to the negative value of the difference between the mean values ( -58.691$)$, it can be concluded that the subjects with aphasia achieved significantly lower scores on all tests compared to the control group.

Differences between the subjects with aphasia and the control group in variables, which are not normally distributed, were tested using the nonparametric Mann-Whitney test. The results are shown in Table 4.

Table 4 shows statistically significant differences between the subjects with aphasia and the control group in all variables, as the significance of the differences between

TABLE 3

DIFFERENCES BETWEEN GROUP 1 AND GROUP 2 FOR NORMALLY DISTRIBUTED VARIABLES

\begin{tabular}{lccccc}
\hline Variables & $\begin{array}{c}\text { Levene's variance } \\
\text { homogeneity test }\end{array}$ & $\begin{array}{c}\text { Significance of } \\
\text { Levene's test }-\mathrm{p} 1\end{array}$ & t-test & $\begin{array}{c}\text { Significance of } \\
\text { the t-test }-\mathrm{p} 2\end{array}$ & $\begin{array}{c}\text { Differences between } \\
\text { arithmetic means }\end{array}$ \\
\hline AGE & 0.606 & 0.441 & 5.590 & 0.000 & 16.9250 \\
FWTL & 6.168 & 0.017 & -3.757 & 0.001 & -2.874 \\
SINR & 6.080 & 0.018 & -6.601 & 0.000 & -4.724 \\
SUM TOTAL & 14.232 & 0.001 & -10.383 & 0.000 & -58.691 \\
\hline
\end{tabular}


TABLE 4

DIFFERENCES BETWEEN THE SUBJECTS WITH APHASIA AND THE CONTROL GROUP, USING THE MANN-WHITNEY TEST

\begin{tabular}{lccccccc}
\hline Variables & $\begin{array}{c}\text { Median } \\
\text { GROUP1 }\end{array}$ & $\begin{array}{c}\text { Median } \\
\text { GROUP2 }\end{array}$ & $\begin{array}{c}\text { Middle ranks } \\
\text { GROUP1 }\end{array}$ & $\begin{array}{c}\text { Middle ranks } \\
\text { GROUP2 }\end{array}$ & Mann-Whitney U & Z & $\begin{array}{c}\text { Asymp. Sig. } \\
\text { (2-tailed)-significance }\end{array}$ \\
\hline FWTR & 9 & 15 & 12.41 & 33.03 & 9.500 & -5.401 & 0.000 \\
SINL & 9 & 12 & 14.54 & 30.58 & 58.500 & -4.234 & 0.000 \\
DTWR & 2 & 27 & 12.54 & 32.88 & 12.500 & -5.317 & 0.000 \\
DTWL & 14 & 28 & 14.59 & 30.53 & 59.500 & -4.168 & 0.000 \\
DTSR & 1 & 10 & 14.98 & 30.08 & 68.500 & -4.112 & 0.000 \\
DTSL & 4 & 10 & 13.46 & 31.83 & 33.500 & -5.151 & 0.000 \\
\hline
\end{tabular}

the arithmetic means of Asymp.Sig is $<0.2 \%$. Based on the median and middle ranks, it can be concluded that the subjects with aphasia had, on average, lower scores on all subtests than the control group.

A better overview of the differences between the subjects with aphasia and the control group will be obtained by graphically showing the mean rankings for each variable. This graphical representation is in Figure 1.

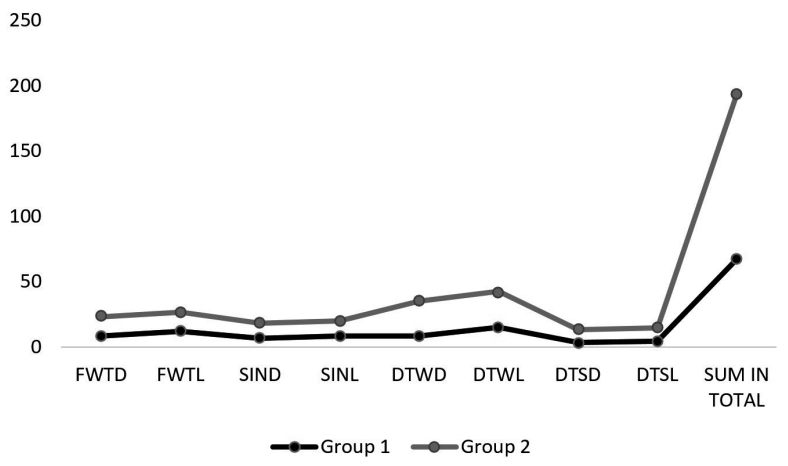

Fig 1. Differences between the subjects with aphasia and the control group.

Regarding the fact of relatively small number of participants, Sign Test was applied to test differences between left and right ear in group of people with aphasia (Table 5) and in the control group (Table 6). Results indicate that people with aphasia and control group showed better results in favor of left ear on speech in noise test. Filtered words were easily processed through left ear in people with aphasia while dichotic sentences were easily processed through left ear in control group.

\section{Discussion}

Statistically lower results on both monoaural tests indicate poorer word recognition. It means that in this case it is even more difficult to listen, or to understand speech in any situation, which can be qualified as acoustically
TABLE 5

SIGN TEST*

\begin{tabular}{cccc}
\hline & Percent $\mathrm{v}<\mathrm{V}$ & $\mathrm{Z}$ & $\mathrm{p}$-level \\
\hline FWT R \& FWT L & 95.4545 & 4.050814 & $\mathbf{0 . 0 0 0 0 5 1}$ \\
SIN R \& SIN L & 80.9524 & 2.618615 & $\mathbf{0 . 0 0 8 8 2 9}$ \\
DTWR \& DTW L & 70.0000 & 1.565248 & 0.117525 \\
DTS R \& DTS L & 57.8947 & 0.458831 & 0.646355 \\
\hline
\end{tabular}

*Marked tests are significant for Group 1

TABLE 6

SIGN TEST*

\begin{tabular}{cccc}
\hline & Percent v $<$ V & Z & p-level \\
\hline FWT R \& FWT L & 60.0000 & 0.516398 & 0.605577 \\
SIN R \& SIN L & 100.0000 & 4.006938 & $\mathbf{0 . 0 0 0 0 6 2}$ \\
DTW R \& DTW L & 72.2222 & 1.649916 & 0.098960 \\
DTS R \& DTS L & 100.0000 & 2.041241 & $\mathbf{0 . 0 4 1 2 2 7}$ \\
\hline
\end{tabular}

*Marked tests are significant for Group 2

unfavorable. Obtained results are in accordance with the results confirming significantly worse ability to understand speech in persons with aphasia in suboptimal conditions, whether it is a distorted signal or background noise ${ }^{17,18}$. Aphasia significantly impairs language comprehension by placing the person in a very unfavorable communication position. Difficulties at the level of perception of the auditory signal further impede auditory discrimination or impair the recognition of the phonemic content of a word determined by auditory analysis. The lexical model ${ }^{19}$ implies that language comprehension involves numerous process stages. The phonemic content of a word is defined by auditory analysis and word recognition occurs when access to the vocabulary is achieved, and understanding is possible when the form of a word is related to its semantic representation. Griffith ${ }^{2}$ states that auditory processing disorders involve numerous mechanisms of the ascending auditory pathway and cortex, and any part of this pathway may be impaired in a person with aphasia. 
The same trend of results continues with the dichotic word and sentence tests. These are tests of competence and measure the ability of binaural integration and binaural separation. A study by Musiek et al. ${ }^{20}$ showed positive correlations between the dichotic listening subtests (numbers) and the sentence competence test for both ears regardless of which side the impairment was located. This confirms that, for the population with cortical lesions, almost $40 \%$ variance of the binaural integration and binaural separation came from the same or similar impairment of auditory function, whether the test was performed ipsi or contralateral. The inability, or the reduced ability to integrate and separate the information obtained through the auditory channel, indicates the reduced efficiency of neurological connections in the auditory system - the impaired ability to direct auditory attention to the desired stimulus and the ability to ignore another, less important, stimulus.

Studies examining ear preference have shown that right ear preference for verbally presented content is related to chronological age. It is clearly expressed in subjects up to 40 years of age, after which this phenomenon is lost in such clear form ${ }^{21}$. This research showed that the dichotic word test was sensitive to the presence of brain injuries, whether chronic or acute, and that the age of the subjects was significant for its prediction. Results regarding the right ear advantage (REA) reduction were obtained in the study by van Ettinger-Veenstra et al. on healthy subjects ${ }^{22}$. They correlated the reduced advantage of the right ear with the decreased activity of the left hemisphere, resulting in better performance on all applied language tests, including reading, language skills, fluency, and discrimination of non-speech stimuli. The authors linked this finding to the phenomenon of the right hemisphere support (homologous parts on the right side) to the left hemisphere when performing language tasks. In people with brain damage, the data confirm the benefit of the left ear, which is consistent with the results achieved by the subjects with aphasia in this study.

The data obtained demonstrates that people with aphasia and control group showed better results in favor of left ear on speech in noise test. Filtered words were easily processed through left ear in people with aphasia while dichotic sentences were easily processed through left ear in control group.

The interpretation of these results is neither simple nor straightforward. Based on this study's findings, it can be confirmed the left ear advantage for monoaural test in people with aphasia but not for competence tests (dichotic word test and dichotic sentence test). Why is that so? Research conducted by Beck at al. ${ }^{23}$ showed that the most frequent complaint in people with and without hearing impairment is the inability to understand speech in noise. He also concludes that individual's speech in noise performance cannot be reliably predicted for his or her speech in quite performance. If we take into consideration that speech in noise is very demanding task for most of the people, we can draw a very tentative conclusion that people with aphasia use a compensatory mechanism of the right hemisphere support in both monaural tests. People in control group, who are also beyond the optimal age regarding auditory processing, use this mechanism only for more demanding tasks, in this case, during the speech in noise test.

When analyzing data from competence tests (dichotic word test and dichotic sentence test), people with aphasia show no preference to either ear although their showed performances are slightly better on left ear but there is no statistically significant difference. Whether tasks are too demanding or the subjects are unable to use the right hemisphere's compensatory mechanisms is very difficult to conclude. On the other hand, left ear advantage for a dichotic sentence test seen in the control group leads us to this conclusion. Is it possible that left ear advantage is the consequence of the right hemisphere support phenomena described in research conducted by van Ettingher-Veenstra et al..$^{22}$ also on healthy subjects? If we take into consideration that the dichotic sentence test is more demanding than dichotic word test, it may be tentatively concluded that healthy control subjects were using compensatory strategies of listening while performing more demanding tasks. Patients with aphasia are a very heterogeneous group. We tried to homogenize the group reducing the participants to those who were able to repeat a sentence with at least six elements. Therefore, we can say that only participants with sufficient comprehension needed to fulfill the tasks were enrolled in the study. So, results from this study can be explained as an achievement of people with a mild type of expressive aphasia yet without fully excluded comprehension difficulties. The goal of this study was to investigate the ability of auditory processing regarding the type of aphasia. However, based on the results of this research, it can be concluded that persons with aphasia achieved statistically significantly lower results on all subtests of the Auditory Processing Test. As far as left ear advantage is concerned, the conclusion is not straightforward and further research is needed to address this question.

\section{Conclusion}

Auditory processing in individuals with aphasia was significantly worse compared to the control group regarding all subtests of the Auditory Processing Test (PSP-1 test). Despite the impact and apparent prevalence of auditory disorders in people with aphasia, little attention has been paid regarding setting therapy goals, whether it is a disorder per se or a clinical symptom accompanying aphasia. Research has shown that focused therapeutic procedures can improve phonemic discriminatory abilities ${ }^{24}$ and, in the light of the confirmed presence of auditory processing disorders, it is essential to create rehabilitation goals aimed to improve listening skills in adults with aphasia. In this way, many difficulties that patients face in everyday life can be prevented, such as difficulties in understanding speech in noise, in selective listening in conditions when a person is involved in a conversation between several persons, in localization of sound, and in talking over the phone etc. Therefore, it is necessary to 
look at the potential of the auditory processing variable in evaluating functional language recovery after stroke.

\section{Limitations of the Study}

Future research should certainly consider the age of the subjects to ensure the experimental and control groups' ages are chronologically equal. In this study, the group of subjects in the experimental group was slightly older than the control group. Although care was taken not to include persons below the age of 30 when auditory potency is the best, future research should take care to equalize the age of participants as much as possible. The sample included subjects with aphasia and the only condition needed for the examination was the ability to repeat the sentence and their ability to cooperate. Certainly, the inclusion conditions should be narrower in order to ensure homogeneity of the samples. Also, all participants were right-handed, which led to the conclusion about lateralization. This determination process should be further defined in future research. Also, future research in this area should include not only triage audiometry but pure-tone audiometry in order give us a better understanding of a patient's hearing profile.

\section{R E F E R E N C E S}

1. HEĐEVER M, NIKOLIĆ B, FABIJANOVIĆ A, Hrvat Rev Za Rehabil Istraz, 49-1 (2013) 49. - 2. GRIFFITHS TD, Brit Med Bull, 63-1 (2002) 107. - 3. NASCIMENTO MSR, MUNIZ LF, COSTA ML, Rev CEFAC, 16-2 (2014) 634. - 4. BAMIOU DE, WERRING D, COX K, STEVENS J, MUSIEK FE, BROWN MN, LUXON LM, Stroke, 43-5 (2012) 1285. - 5. NICCUM, N, Brain Lang, 28-2 (1986) 273. - 6. NICCUM N, SPEAKS C, RUBENS AB, KNOPMAN DS, YOCK D, LARSON, D, Brain Lang, 28-2 (1986) 289. - 7. NICCUM N, SELNES OA, SPEAKS C, RISSE GL, RUBENS AB, Brain Lang, 28-2 (1986) 303. - 8. KIMURA D, Can J Psychol, 15 (1961) 166. - 9. ORTIZ KZ, PERONI C, Rev CEFAC, 10-2 (2008) 226. - 10. SHISLER RJ, Aphasiology, 19-7 (2005) 633. - 11. KIESSLING J, PICHORA FULLER MK, GATEHOUSE S, STEPHENS D, ARLINGER S, CHISOLM T, DAVIS AC, ERBER NP, HICKSON L, HOLMES A, ROSENHALL U, VON WEDEL H, Int J Audiol, 42-suppl 2 (2003) 92. - 12. BRITISH SOCIETY OF AUDIOLOGY, Auditory Processing Disorder. British Society of Audiology Steering Group, 2007: http://www.thebsa.org/uk/apd/BSA_APD:Position_statemnt_Final_ Draft_Feb_2007.pdf. - 13. AMERICAN SPEECH-LANGUAGE-HEARING ASSOCIATIONS, Central auditory processing disorders, 2005: http://www.asha.org/docs/html/PS2005-00114html. - 14. PEDALINI MEB, SANCHEZ TG, DANTONIO A, DANTONIO W, BALBANI A,
HACHIYA A, LIBERMAN S, BENTO RF, Pró-Fono R Atual Cient, 12 (2000) 17. - 15. HEĐEVER M, Test Battery for Auditory Processing Disorders PSP1 (In Croat) (Faculty of Education and Rehabilitation Sciences, University of Zagreb, 2011). - 16. HEĐEVER M, Test PSP-1: test za ispitivanje poremećaja slušnog procesiranja, IV. (Tara centar, Zagreb, 2018). - 17. MOINEAU S, DRONKERS N, BATES E, J Speech Lang Hear R, 48 (2005) 884. - 18. LEICHTY J, Living with aphasia, a communication disorder, 2012: https://www.natcom.org/communication-currents/living-aphasia-communication-disorder. - 19. WHITWORTH A, WEBSTER J, HOWARD D, Cognitive neuropsychological approach to assessment and intervention in aphasia: a clinician's guide (Psychology Press, Hove, 2014). - 20. MUSIEK FE, CHERMAK, GD, WEIHING, J, ZAPPULLA, M, NAGLE, S, J Am Acad Audiol, 22 (2011) 342. - 21. MEYERS JE, ROBERTS R, BAYLES JD, VOLKERT K, EVERTS KE, Arch Clin Neuropsychol, 17 (2002) 79. - 22. VAN ETTINGER VEENSTRA HM, RAGNEHED M., HALLGREN M., KARLSON T., LANDTBLOM AM, LUNDBERG P., ENGSTROM M, Neuroimage, 49 (2010), 3481. - 23. BECK DL, NG E, JENSEN JJ, Hear Rev, 26-2 (2019) 28. -24 . WOOLF C, PANTON A, ROSEN S, BEST W, MARSHALL J, Aphasiology, 28-12 (2014) 1481.

\section{K. Pavičić Dokoza}

The SUVAG Polyclinic, Ljudevita Posavskog 10, 10000 Zagreb, Croatia

e-mail: kpavicic@suvag.hr 


\section{SLUŠNO PROCESIRANJE KOD OSOBA S KRONIČNOM AFAZIJOM}

\section{S A Ž E T A K}

Preduvjeti uspješne govorne komunikacije su dobar sluh i slušanje, te slušno procesiranje koje uključuje sposobnost obrade zvučnog signala. Oštećenja ili usporavanja obrade zvučnog signala na bilo kojoj razini od periferije do središnjih struktura dovodi do dezintegracije i nemogućnosti učinkovite obrade signala. U Hrvatskoj do sada nije ispitivano slušno procesiranje kod osoba s afazijom. Rezultati istraživanja provedenih u drugim jezicima upućuju na negativan utjecaj poremećaja slušnog procesiranja na receptivnu i ekspresivnu sastavnicu jezika. Istraživanje je provedeno na uzorku ispitanika s kroničnom afazijom i skupini kontrolnih ispitanika bez neuroloških ili drugih bolesti koje mogu utjecati na slušno procesiranje. Kriteriji uključivanja osoba s afazijom su bili sljedeći: slabije jezične sposobnosti kao posljedica CVI koji se dogodio najmanje šest mjeseci prije ispitivanja bez obzira na težinu i vrstu afazije te uredan sluh. U istraživanje nisu uključene osobe $\mathrm{s}$ afazijom koje nisu bile u mogućnosti za ispitivačem ponoviti rečenicu od šest riječi, bez obzira radi li se o poremećaju razumijevanja ili govorne ekspresije, te osobe kod kojih razumijevanje nije bilo dovoljno za dobru suradnju tijekom provođenja testa. Ispitivanje je provedeno individualno u trajanju od tridesetak minuta po ispitaniku pomoću testa PSP-1 koji je standardiziran za hrvatski jezik. Dobiveni rezultati pokazuju statistički značajno slabija postignuća na svim subtestovima Testa slušnog procesiranja (filtrirane riječi, govor u buci, dihotički test riječi, dihotički test rečenica) kod osoba $\mathrm{s}$ afazijom $\mathrm{u}$ odnosu na kontrolne ispitanike. Osobe $\mathrm{s}$ afazijom i skupina kontrolnih ispitanika pokazuju statistički značajne razlike u smislu boljih rezultata na lijevom uhu na varijabli govor u buci. Filtrirane riječi su osobe s afazijom bolje procesirale na lijevo uho dok su kontrolni ispitanici na lijevo uho bolje procesirali rečenice na subtestu dihotički test rečenica. Rezultati potvrđuju hipotezu o prisustvu poremećaja slušnog procesiranja kod osoba s afazijom i u skladu su s ranije provedenim istraživanjima na drugim jezicima. Osim toga, ukazuju na potrebu uvođenja specifičnih terapijskih postupaka u rehabilitaciji u cilju poboljšanja funkcije slušnog procesiranja kod osoba nakon moždanog udara. 